\title{
MONO-, TRINUCLEAR NICKEL(II) AND COPPER(II) DIOXIME COMPLEXES: SYNTHESIS, CHARACTERIZATION, CATECHOLASE AND CATALASE-LIKE ACTIVITIES, DNA CLEAVAGE STUDIES
}

\author{
FATMA KARIPCIN ${ }^{1 *}$, BULENT DEDE ${ }^{2}$, ISMAIL OZMEN², MURAT CELIK², EKREM OZKAN ${ }^{2}$
}

${ }^{\prime}$ Department of Chemistry, Sciences and Arts Faculty, Nevsehir Haci Bektas Veli University, 50300, Nevsehir-TURKEY

${ }^{2}$ Department of Chemistry, Sciences and Arts Faculty, Süleyman Demirel University, 32260, Isparta-TURKEY

\begin{abstract}
The synthesis and molecular structures of six new mono- and trinuclear complexes $\left[\mathrm{M}^{1} \mathrm{~L}_{2}\left\{\mathrm{M}^{2}(\text { phen })\right\}_{2}\right]\left(\mathrm{ClO}_{4}\right)_{2}\left[\mathrm{phen}=1,10\right.$-phenanthroline, $\mathrm{H}_{2} \mathrm{~L}=$ dioxime ligand, $\mathrm{M}^{1}, \mathrm{M}^{2}=\mathrm{Ni}(\mathrm{II})$ and $\mathrm{Cu}(\mathrm{II})$ ] of the ligand, 4-(4-methylphenylamino)biphenylglyoxime are reported. Structural assignments are supported by a combination of FT-IR, elemental analyses, ICP-OES, magnetic susceptibility and molar conductivity studies. Furthermore these complexes were each tested for their ability to catalyze the oxidation of catechol substrates to quinone with dioxygen at $25^{\circ} \mathrm{C}$ and disproportionation of hydrogen peroxide in the presence of the added base imidazole. The catalytic results indicated that the heterotrinuclear $\mathrm{Cu}(\mathrm{II}) \mathrm{Ni}(\mathrm{II}) \mathrm{Cu}(\mathrm{II})$ complex (5) shows greater catecholase activity. On the other hand the trinuclear complexes display efficiency in disproportion reactions of hydrogen peroxide producing water and dioxygen in catalase-like activity and homotrinuclear $\mathrm{Cu}$ (II) (6) complex is more active towards catalytic decomposition of hydrogen peroxide. The interaction between these compounds with DNA has also been investigated by agarose gel electrophoresis, the trinuclear copper(II) complexes $(\mathbf{5 , 6})$ with $\mathrm{H}_{2} \mathrm{O}_{2}$ as a cooxidant exhibited the strongest cleaving activity.
\end{abstract}

Keywords: Dioxime; Trinuclear complex; Catecholase like activity; Catalase like activity; DNA cleavage; 1,10-phenantroline

\section{INTRODUCTION}

Vic-dioximes and their derivatives are a very important class of ligands, forming complexes with transition metal cations. Some oximes are widely used for various purposes in organic, analytical, inorganic, bio and industrial chemistry. The coordination chemistry of vicinal dioximes is interesting and numerous transition metal complexes of these ligands have been investigated. ${ }^{1,2}$ The presence of mildly acidic hydroxyl groups and slightly basic nitrogen atoms makes vic-dioximes amphoteric ligands which from square-planar, square-pyramidal or octahedral complexes with transition metal ions such as $\mathrm{Cu}(\mathrm{II}), \mathrm{Ni}(\mathrm{II})$ and $\mathrm{Co}(\mathrm{II})$ as central atoms. ${ }^{2-5}$ These kinds of ligands have been shown site specificity of metal ions in producing trinuclear complexes depending on the synthetic procedure and nature of counterions used. ${ }^{6-8}$

The complexation of appropriate metals is critical in the biological function of many enzymes and it has been shown that catalytic activity in several enzyme models is dependent on nuclearity; mononuclear complexes often appear to exhibit a decrease in, or absence of, catalytic activity in contrast to their multinuclear counterparts. ${ }^{9-12}$ During the last decade, great attention was given to the area of multinuclear complexes with extended bridges. ${ }^{8,13-14}$ Multinuclear transition metal active sites that are involved in the catalysis of reactions vital to biological systems are being steadily recognized and studied. ${ }^{15,16}$

Copper is a physiologically important element and many enzymes that depend on copper for their activity have been identified. Because of its biological relevance, a large number of copper(II) complexes have been synthesized and explored for their biological activities. ${ }^{16-19}$ Among these copper complexes, attention has been mainly focused on the copper(II) complexes of 1,10-phenanthroline ligand, due to their high nucleolytic efficiency ${ }^{17}$ and numerous biological activities such as antitumor, ${ }^{18}$ anti-candida ${ }^{20}$ and antimicrobial ${ }^{19,21}$ activities, etc.

Nickel has been found in ureases ${ }^{22,23}$ hydrogenases, CO dehydrogenases and coenzyme F430. ${ }^{24}$ Hydrogenases occur in many bacteria where they are responsible for catalyzing the oxidation of molecular hydrogen, while CO dehydrogenase interconverts carbon monoxide and carbon dioxide. Hydrogenases and CO dehydrogenases have nickel(III) (low spin $\left.d^{7}\right){ }^{24}$ Nickel(II) exists in a square planar geometry in Coenzyme F430 which is a cofactor of methyl coenzyme $\mathrm{M}$ reductase. ${ }^{12}$

A number of copper containing multinuclear complexes have been studied catalase and catecolase like activity ${ }^{15,16,25,26}$ but catalytically active complexes containing other transition metal ions such as $\mathrm{Mn}$, Co or $\mathrm{Ni}^{12,27,28}$ are also known. Catalase enzymes can dismute hydrogen peroxide, a reaction which is important for cell detoxification, and is linked to a variety of pathological consequences such as aging, diabetes and cancer. ${ }^{29}$ On the other hand the catechol oxidases are a group of containing copper enzymes. They catalyze the oxidation of o-diphenols (catechol, Cat) to o-quinones (Q) and play diverse physiological roles in various organisms, such as the biosynthesis of catecholamine neurotransmitters and hormones (dopamine, noradrenaline, adrenaline) of humans and vertebrates, as well as the formation of the pigment melanin, browning of fruits and vegetables, when they are injured..$^{30,31}$

Among the copper containing complexes, particularly copper 1,10-phenanthroline complexes in the presence of $\mathrm{H}_{2} \mathrm{O}_{2}$ efficiently cleave DNA. ${ }^{32,33}$ The DNA cleavage reactions generally proceed via three major pathways, viz. oxidative strand cleavage by abstraction of sugar hydrogen atom(s), hydrolytic cleavage involving the phosphate group, and by base oxidations primarily directed at the guanine base. ${ }^{34}$ Although there are reports ${ }^{35-38}$ of copper complexes cleaving DNA hydrolytically or in an oxidative manner in the presence of a reducing agent, the chemistry of copper complexes showing visible light-induced photocleavage is virtually unexplored..$^{34,39,40} \mathrm{We}$ have previously described the preparation and DNA cleavage properties of oxime ligands which are capable of chelating two metal ions and in which the coordinating moieties are separated by 1,10 -phenanthroline. ${ }^{16,41}$ In this paper, we report the synthesis and structural assignment of a series of new mono- and trinuclear copper(II) and nickel(II) 4-(4-methylphenylamino) biphenylglyoximato complexes using 1,10-phenanthroline, and catecholase and catalase-like activities of these complexes. Furthermore, the interactions with plasmid DNA (pBR322 DNA) employing gel electrophoresis of the compounds are also investigated.

\section{EXPERIMENTAL}

Materials : All reagents were purchased from commercial sources and used as received and all aqueous solutions were prepared with deionized water The dioxime ligand, 4-(4-methylphenylamino)biphenylglyoxime $\left(\mathrm{H}_{2} \mathrm{~L}\right)$ was synthesized according to the procedure described previously., 42

Physical Measurements: Microanalyses $(\mathrm{C}, \mathrm{H}$ and $\mathrm{N})$ were carried out using a LECO 932 CHNS analyzer. Copper and nickel were analyzed on a Perkin Elmer Optima 5300 DV ICP-OES spectrometer. The IR spectra were recorded as KBr pellets on a Shimadzu IRPrestige-21 FT-IR Spectrophotometer. UV-VIS spectra were obtained on a Perkin Elmer Lambda 20 UV-VIS Spectrometer. Magnetic susceptibility measurements were carried out at room temperature on a Sherwood Scientific Magnetic Susceptibility Balance (Model MX1). Conductivity measurements were carried out on Optic Ivymen System conductivity meter. Melting point determinations were performed with a digital melting point instrument (Electrothermal model IA 9100). 
Synthesis of Complexes: Caution! Perchlorate salts of metal complexes are potentially explosive. Only a small amount of the material is to be used at a time and should be handled with care.

Synthesis of the mononuclear complexes (1-2): Mononuclear complexes $\left[\mathrm{ML}_{2}\right]$ were obtained by the reaction of $\mathrm{M}(\mathrm{II})\left(\mathrm{ClO}_{4}\right)_{2}(1 \mathrm{mmol})$ with dioxime ligand $(2 \mathrm{mmol})$ in EtOH. A quantity of $(2 \mathrm{mmol})$ dioxime ligand, $\mathrm{H}_{2} \mathrm{~L}$ was dissolved in $20 \mathrm{~mL}$ absolute EtOH, then the solution of $\mathrm{M}(\mathrm{II})\left(\mathrm{ClO}_{4}\right)_{2}(1 \mathrm{mmol})$ in $20 \mathrm{~mL}$ water-EtOH $(3: 1)$ mixture was added dropwise with stirring. The $\mathrm{pH}$ of the reaction mixture was around 3.0-3.5 and then was adjusted to $5.0-5.5$ by adding $1 \% \mathrm{NaOH}$ solution. The precipitated complex was kept in a water bath at $60^{\circ} \mathrm{C}$ for $30 \mathrm{~min}$, then filtered while hot, washed with water, $\mathrm{EtOH}$ and $\mathrm{Et}_{2} \mathrm{O}$ and dried over $\mathrm{P}_{2} \mathrm{O}_{5}$

Synthesis of the trinuclear complexes (3-6): To an absolute $\mathrm{MeOH}$ solution $(10 \mathrm{~mL})$ of $\left[\mathrm{ML}_{2}\right](0.1 \mathrm{mmol})$ and $\mathrm{Et}_{3} \mathrm{~N}(1 \mathrm{~mL})$ was added an absolute $\mathrm{MeOH}$ solution $(20 \mathrm{~mL})$ containing $\mathrm{M}(\mathrm{II})\left(\mathrm{ClO}_{4}\right)(0.2 \mathrm{mmol})$ and phen $(73.9$ $\mathrm{mg}, 0.4 \mathrm{mmol}$ ). After the mixture was boiled under reflux for a few min, with stirring, the complexes were deposited. The reflux continued for ca. $1.5 \mathrm{~h}$. The mixture was then allowed to cool to room temperature and the colored powders obtained were removed by filtration, washed several times with $\mathrm{MeOH}$ and $\mathrm{Et}_{2} \mathrm{O}$ and dried over $\mathrm{P}_{2} \mathrm{O}_{5}$.

Catecholase-like Activity Studies: The catecholase activity has been studied in DMF by reaction of the complexes with 3,5-di-tert-butylcatechol (3,5-DTBC). For this purpose a $1 \times 10^{-4} \mathrm{M}$ solution of the complexes was treated with 50 equiv. of 3,5-DTBC under aerobic condition. The increase in absorption band at $395 \mathrm{~nm}$, characteristic of the 3,5-di-tert-butyl-o-benzoquinone (3,5DTBQ), was followed spectrophotometrically at various time intervals from 3 to $45 \mathrm{~min}$.

Catalase-like Activity Studies: The disproportionation reaction was carried out in the air in a $50 \mathrm{~mL}$ reactor containing a stirring bar. To $10 \mathrm{~mL}$ DMF was added a sample of the complex ( $0.005 \mathrm{mmol}$ solid sample) and the flask was sealed with a rubber septum. Hydrogen peroxide $(1.33 \mathrm{mmol}, 0.150 \mathrm{~mL})$ was injected through the septum with a syringe. The reactor was connected to a graduated gas burette filled with water and dioxygen evolution was measured at $1 \mathrm{~min}$ time intervals by volumometry. In cases where imidazole $(50 \mathrm{mg})$ was added this was introduced into the reaction vessel before the addition of $\mathrm{H}_{2} \mathrm{O}_{2}$ (in the absence of the imidazole the complexes were either inactive or very weak catalysts for this reaction).

DNA Cleavage: The cleavage of DNA was monitored using agarose gel electrophoresis. In a typical experiment, $0.25 \mu \mathrm{g} / \mathrm{mm}^{3}$ supercoiled $\mathrm{pBR} 322$ DNA $\left(0.5 \mathrm{~mm}^{3}\right)$ was treated with $1.5 \mathrm{~mm}^{3}$ of $1 \mathrm{mM}$ solutions of the ligand and the complexes in DMF and $2 \mathrm{~mm}^{3}$ of $0.1 \mathrm{M}$ Tris- $\mathrm{HCl}(\mathrm{pH} 8.0)$ buffer in the absence and presence of $4 \mathrm{~mm}^{3}$ of $5.0 \mathrm{mM}$ hydrogen peroxide as a cooxidant reagent. The samples were incubated for $2 \mathrm{~h}$ at $37^{\circ} \mathrm{C}$. Loading buffer containing $0.25 \%$ bromophenol blue, $0.25 \%$ xylene cyanol, $30 \%$ glycerol in $\mathrm{H}_{2} \mathrm{O}\left(1 \mathrm{~mm}^{3}\right)$ was added and the mixed solution was loaded on $1 \%$ agarose gel. The electrophoresis was carried out for $1.5 \mathrm{~h}$ at $100 \mathrm{~V}$ in TBE buffer $(89 \mathrm{mM}$ Tris-borate, $\mathrm{pH} 8.3,2.5 \mathrm{mmol} / \mathrm{dm}^{3}$ EDTA). Gels were stained with ethidium bromide $\left(1 \mathrm{mg} / \mathrm{cm}^{3}\right)$ for $10 \mathrm{~min}$ prior to being photographed under UV light. The efficiency of the DNA cleavage was measured by determining the ability of the complex to form linked circular (LC) or nicked circular (NC) DNA from its supercoiled (SC) form by quantitatively estimating the intensities of the bands using the DNR Minibis Pro Gel Documentation System. The fraction of each form of DNA was calculated by dividing the intensity of each band by the total intensities of all the bands in the lane.

\section{RESULTS AND DISCUSSION}

The synthesis of the dioxime ligand has been reported previously. ${ }^{3,42}$ The melting points, yields, colors, magnetic susceptibility, molar conductivity values and elemental analyses of the complexes and the ligand are summarized in Table 1. All complexes are stable at room temperature and soluble in DMSO and DMF. Unfortunately, we could not obtain any single crystal for the ligand and its complexes were not suitable for crystallographic studies. However, the analytical, spectroscopic and magnetic data enables us to predict possible structures as shown in Figure 1. The metal-ligand ratio was found to be 1:2 for mononuclear complexes and 3:2 for trinuclear complexes according to the elemental analysis results.

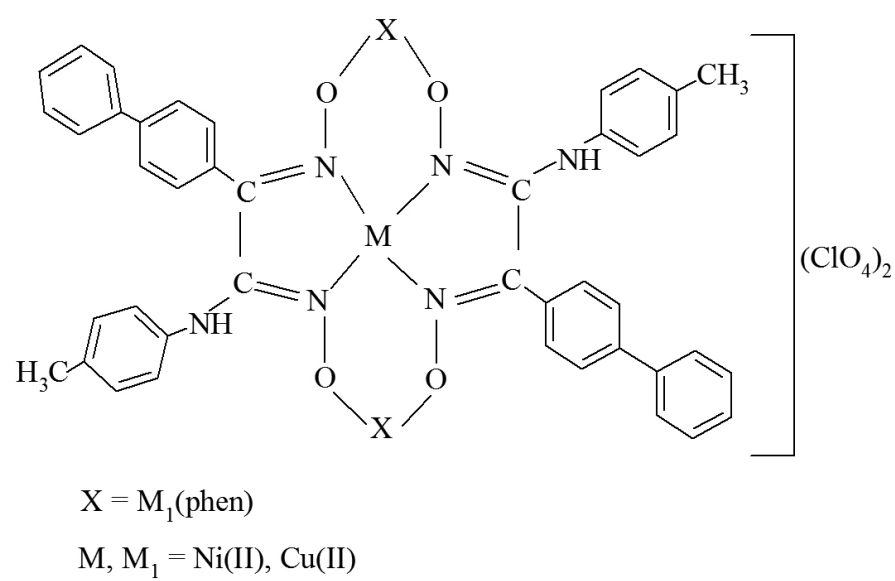

Figure 1. The proposed structure of the trinuclear dioxime complexes.

Molar Conductivities: Conductivity measurements have frequently been used in the structural elucidation of metal chelates within the limits of their solubility. The complexes were dissolved in DMF and the molar conductivities of their $1 \times 10^{-3} \mathrm{M}$ solutions at $25^{\circ} \mathrm{C}$ were measured. The molar conductivity values of the complexes are given in Table 1 . The molar conductivity value for the free ligand in DMF solvent $\left(1 \times 10^{-3} \mathrm{M}\right)$ was $5.24 \mathrm{Scm}^{2} \mathrm{~mol}^{-1}$. The molar conductivity values of the mononuclear complexes $(\mathbf{1}, \mathbf{2})$ are 7.6 and $8.6 \mathrm{Scm}^{2} \mathrm{~mol}^{-1}$, which indicated their non-ionic nature. ${ }^{43,44}$ The trinuclear complexes (3-6) behaved as ionic compounds which gave molar conductivity 152.2-178.3 Scm $\mathrm{Smol}^{-1}$. These values indicated that the trinuclear complexes containing perchlorate ions behave as 1:2 electrolytes. ${ }^{41,45}$

Magnetic Susceptibility Measurements: As further structural tools, the room temperature magnetic studies have been used to confirm the geometry of the complexes. The results show that mononuclear nickel(II) complex (1) is diamagnetic, indicating the low-spin $(\mathrm{S}=0)$ square planar $\mathrm{d}^{8}$-system. The magnetic moment of the mononuclear copper(II) (2) complex is found to be 1.48 B.M. indicating $\mathrm{d}^{9}$-system. The magnetic moments of the trinuclear $\mathrm{Ni}_{3}(3)$ and $\mathrm{CuNi}_{2}(4)$ complexes are found 2.58 and 3.32 B.M. and the magnetic moments of the other trinuclear $\mathrm{NiCu}_{2}(\mathbf{5})$ and $\mathrm{Cu}_{3}(\mathbf{6})$ complexes are found 2.26 and 1.51 B.M., respectively. These values are slightly lower than the spin-only value of nickel(II) and $\mathrm{Cu}(\mathrm{II})$ ions, implying the operation of an antiferromagnetic spinexchange interaction. Because the central nickel(II) ion with a square-planar environment is diamagnetic, the trinuclear complexes of nickel(II) $(3,4)$ can be considered as a homodinuclear nickel(II)-nickel(II) systems. Considering the symmetry of the $\mathrm{Ni}\left(\mathrm{N}_{4} \mathrm{O}_{4}\right) \mathrm{Ni}$ skeleton of the dioximate bridging network as close to $\mathrm{C}_{2}$, the two unpaired electrons of the terminal nickel(II) ion occupy the $\mathrm{d}_{\mathrm{x}-\mathrm{y}}^{2}$ and $\mathrm{d}_{\mathrm{z}}^{2}$ orbitals, which transform as a irreducible representations of the $\mathrm{C}_{2 v}$ point group. According to group theory, $<\mathrm{a}_{1} \mid \mathrm{a}_{1}>\neq 0$, hence, the antiferromagnetic interaction (between the two terminal nickel(II) ions) should be observed. ${ }^{46,47}$ Some oximate ligands generally mediate very strong antiferromagnetic exchange interactions between $\mathrm{d}^{9} \mathrm{Cu}(\mathrm{II})$ center interaction as reported previously for trinuclear copper complexes with oximate bridge ligands. ${ }^{8,48-50}$ Because of the symmetry properties of the $\delta$ interaction, the $\mathrm{d}_{x-y}^{2}{ }^{2}$ orbitals in the $\mathrm{Cu}(\mathrm{II})$ ions and $\delta$ orbitals of the bridging oxygen atoms are involved in the exchange pathway for the unpaired spin density. ${ }^{49}$ 
Table 1. Some physical properties and elemental analyses of the complexes.

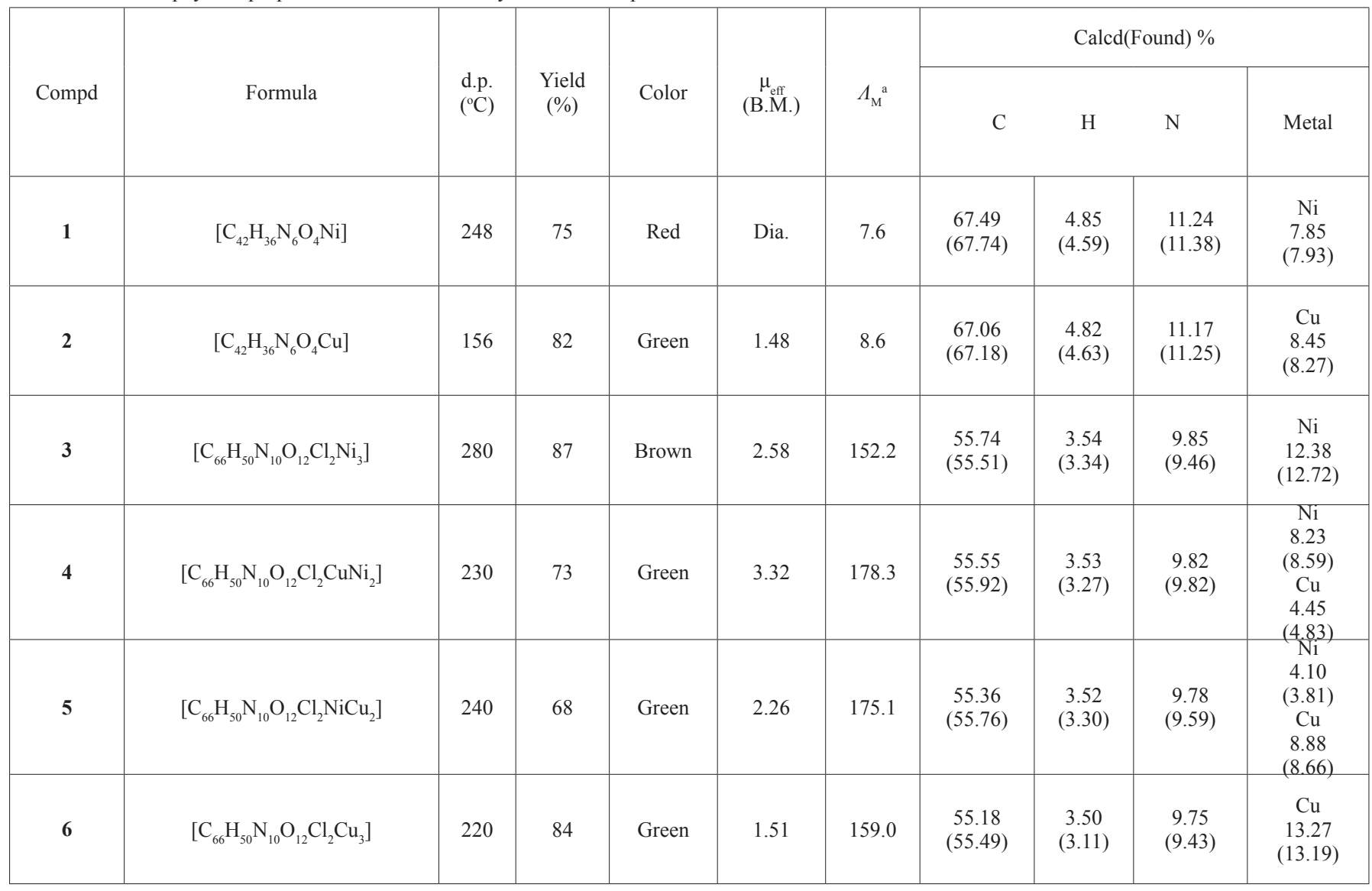

d.p.: Decomposition point, ${ }^{\mathrm{a}}$ Molar conductivity $\left(\mathrm{Scm}^{2} \mathrm{~mol}^{-1}\right)$

IR Spectra: The IR spectra of the mono- and trinuclear complexes exhibit significant differences from that of the free ligand and the characteristic vibrational frequencies have been identified by comparing the spectra of the complexes with their free ligand. The most relevant IR absorption bands for the complexes, together with their assignments, are shown in Table 2.

Table 2. The characteristic IR bands $\left(\mathrm{cm}^{-1}\right)$ of the ligand and its complexes as $\mathrm{KBr}$ pellets.

\begin{tabular}{|c|c|c|c|c|c|c|c|}
\hline Compd & $v(\mathrm{~N}-\mathrm{H})$ & $v(\mathrm{O}-\mathrm{H})$ & $v(\mathrm{C}=\mathrm{N})_{\mathrm{ox}}$ & $v(\mathrm{~N}-\mathrm{O})$ & $v\left(\mathrm{ClO}_{4}\right)$ & $v(\mathrm{M}-\mathrm{O})$ & $v(\mathrm{M}-\mathrm{N})$ \\
\hline $\begin{array}{c}\mathrm{H} \mathrm{L} \\
2\end{array}$ & $3369 \mathrm{~b}$ & $3203 \mathrm{~b}$ & $\begin{array}{c}1637 \mathrm{~s} \\
1610 \mathrm{~s}\end{array}$ & $1393 \mathrm{~m}$ & - & - \\
\hline $\mathbf{1}$ & $3345 \mathrm{~m}$ & $1774 \mathrm{w}$ & $1598 \mathrm{~s}$ & $1381 \mathrm{~m}$ & - & $471 \mathrm{w}$ \\
\hline $\mathbf{2}$ & $3375 \mathrm{~b}$ & $1775 \mathrm{w}$ & $1601 \mathrm{~s}$ & $1387 \mathrm{~m}$ & - & - & $462 \mathrm{w}$ \\
\hline $\mathbf{3}$ & $3345 \mathrm{~m}$ & - & $1584 \mathrm{~m}$ & $1340 \mathrm{~m}$ & $\begin{array}{l}1096 \mathrm{~s} \\
622 \mathrm{~m}\end{array}$ & $503 \mathrm{w}$ & $426 \mathrm{w}$ \\
\hline $\mathbf{4}$ & $3381 \mathrm{~b}$ & - & $1607 \mathrm{~m}$ & $1342 \mathrm{~m}$ & $\begin{array}{l}1096 \mathrm{~s} \\
625 \mathrm{~m}\end{array}$ & $505 \mathrm{w}$ & $426 \mathrm{w}$ \\
\hline $\mathbf{5}$ & $3392 \mathrm{~b}$ & - & $1601 \mathrm{~m}$ & $1378 \mathrm{~m}$ & $\begin{array}{l}1107 \mathrm{~s} \\
624 \mathrm{w}\end{array}$ & $506 \mathrm{w}$ & $468 \mathrm{w}$ \\
\hline $\mathbf{6}$ & $3349 \mathrm{~b}$ & - & $1604 \mathrm{~m}$ & $1345 \mathrm{~m}$ & $\begin{array}{l}1009 \mathrm{~s} \\
625 \mathrm{~m}\end{array}$ & $509 \mathrm{w}$ & $432 \mathrm{w}$ \\
\hline
\end{tabular}


Strong bands in 1635 and $1610 \mathrm{~cm}^{-1}$ in the free ligand assigned to the azomethine $v(\mathrm{C}=\mathrm{N})$ group exhibits shifting to the lower energy (1584$1607 \mathrm{~cm}^{-1}$ ) in the spectra of complexes indicating coordination through the azomethine nitrogen of Schiff bases ${ }^{8,51,52}$ and this can be explained by the interaction of electrons from nitrogen with the empty d-orbitals of the metal atoms. Coordination of the vic-dioxime ligands to the metal center through the four nitrogen atoms are expected to reduce the electron density in the azomethine link and decrease the $v(\mathrm{C}=\mathrm{N})$ absorption frequency. ${ }^{52}$ Formation of a metal-nitrogen bond is further supported by the presence of a band in the region $426-471 \mathrm{~cm}^{-1}$. However, the disappearance of $v(\mathrm{O}-\mathrm{H})$ stretching bands in the IR spectrum of free ligand together with the existence of H-bridge $(\mathrm{OH} \cdots \mathrm{O})$ at $1774-1775 \mathrm{~cm}^{-1}$ and the shifting of $-\mathrm{C}=\mathrm{N}$ and $-\mathrm{N}-\mathrm{O}$ stretches in the IR spectra of the mononuclear complexes $(\mathbf{1 , 2})$ provide support for $\mathrm{MN}_{4}{ }^{-}$ type coordination in the metal complexes. ${ }^{8,53}$

The $v(\mathrm{~N}-\mathrm{O})$ stretching frequencies absorb strongly in $1393 \mathrm{~cm}^{-1}$ in the ligand and shift to $1381-1387 \mathrm{~cm}^{-1}$ in the mononuclear complexes and 1340 $1378 \mathrm{~cm}^{-1}$ in the trinuclear complexes. ${ }^{41,54}$ The shift to lower wave numbers on complexation could be due to a change in the orientation of the $\mathrm{N}-\mathrm{O}$ bond with respect to $\mathrm{H}$ in the ligand and complexes. The complexes appear to have been stabilized by the six-membered chelate ring due to the MNOHONM or MNOMONM moiety.

In the IR spectrum of trinuclear complexes (3-6), the stretching vibration of the intramolecular hydrogen $\left(\mathrm{OH}^{\cdots} \mathrm{O}\right)$ band disappeared upon the encapsulation of the metal ions in the formation of trinuclear metal complexes, namely $\mathrm{Cu}_{2}(1,10-\text { phen })_{2}$ or $\mathrm{Ni}_{2}(1,10 \text {-phen })_{2}$. Formation of a metal-oxygen bond is further supported by the presence of a band in the region 503-509 $\mathrm{cm}^{-1}$. Perchlorate salts show strong antisymmetric stretching band between 1009$1107 \mathrm{~cm}^{-1}$ and sharp antisymmetric stretching band between $622-625 \mathrm{~cm}^{-1}$, an indication of uncoordinated perchlorate anions. ${ }^{7,8,41}$

Catecholase-like Activity Studies: Among the different catechols used in catechol oxidase model studies, 3,5-DTBC is the most widely used substrate due to its low redox potential for the quinone-catechol couple, which makes it easily oxidized to the corresponding quinone 3,5-DTBQ (Fig. 2), and its bulky substituents, which make further oxidation reactions such as ring opening slower. The detection of the oxidation of 3,5-DTBC to the corresponding 3,5DTBQ can be followed by the development of the absorption band at about 40 .

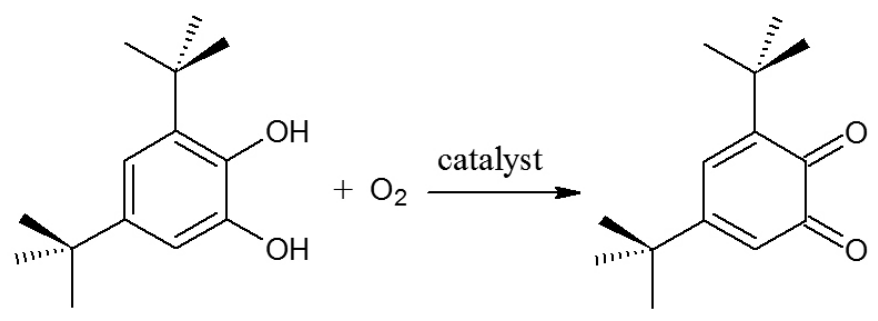

Figure 2. Oxidation of the 3,5-di-tert-butylcatechol by the catalyst

Catalytic studies were performed in N, N-dimethylformamide solution owing to the good solubility of the complex as well as the substrate. The solution of metal complexes and catechol were added together in the spectrophotometric cell at $25^{\circ} \mathrm{C}$. Formation of quinone was monitored by the increase in absorbance at $395 \mathrm{~nm}$ as a function of time. Blank experiments showed that in the absence of catalyst the transformation of 3,5-DTBC to 3,5DTBQ does not take place. The activities of the complexes are very different. The trinuclear complexes are more active (Fig. 3) then the mononuclear complexes. The addition of 50 equivalents of 3,5 -DTBC to the mononuclear complexes has nearly no influence on their UV-Vis spectra in the presence of dioxygen. The observed rate constants, $\mathrm{k}$ values, for the $o$-quinone formation, were obtained from the $\log \left[A_{\infty} / A_{\infty}-A_{t}\right]=k t$ equation where $A_{\infty}$ and $A_{t}$ are the absorbance of the formed $o$-quinone at time $t=\infty$ and $t=t$, respectively. The experiments were repeated several times to ensure consistency of the results. As can be seen from Table 3, $\mathrm{Cu}$ (II)Ni(II)Cu(II) complex $\mathbf{5}$ is the most effective catalyst in the oxidation of 3,5-DTBC to the 3,5-DTBQ compared to the other trinuclear complexes and trinuclear complexes catalyze the oxidation reaction of catechol to quinone with the rate varying from a high of $3.72 \times 10^{-2} \mathrm{~min}^{-1}$ for the complex 5 to weaker rate of $7.6 \times 10^{-3} \mathrm{~min}^{-1}$ for the complex 3. From the obtained rate constant values, it was revealed that the order of catalytic activity towards the oxidation of 3,5-DTBC is $\mathbf{5}>\mathbf{6}>\mathbf{4}>\mathbf{3}$.

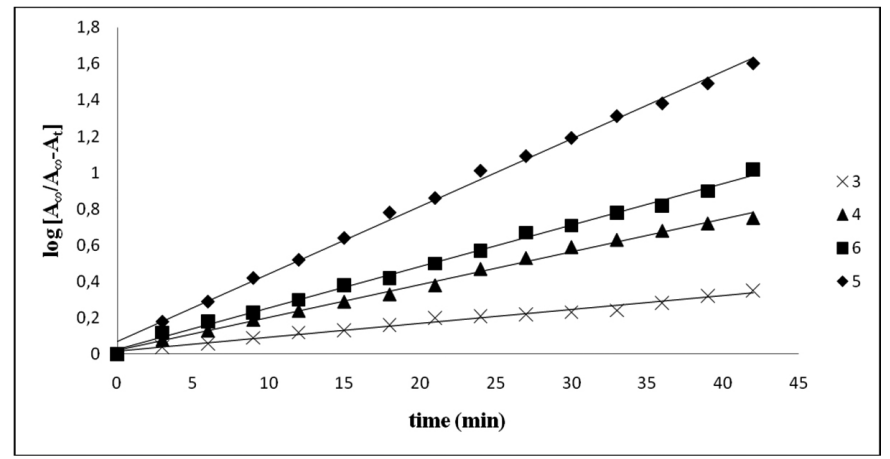

Figure 3. Catalytic oxidation of 3,5-DTBC ( 50 equiv) by the complexes 3 , 4,5 and $6\left(1 \times 10^{-4} \mathrm{M}\right)$ in $\mathrm{N}, \mathrm{N}$-dimethylformamide at $395 \mathrm{~nm}$. The measurements have been done at every 3 min interval

Table 3. The rate constant values of the complexes 3, 4, 5 and 6 for the oxidation of 3,5-DTBC to the corresponding quinone

\begin{tabular}{|c|c|}
\hline Complex & Rate constant, $\mathrm{k}\left(\mathrm{min}^{-1}\right)$ \\
\hline $\mathbf{3}$ & $7.6 \times 10^{-3}$ \\
\hline $\mathbf{4}$ & $1.82 \times 10^{-2}$ \\
\hline $\mathbf{5}$ & $3.72 \times 10^{-2}$ \\
\hline $\mathbf{6}$ & $2.28 \times 10^{-2}$ \\
\hline
\end{tabular}

It is known that binuclear copper complexes are generally more reactive towards the oxidation of catechols than are the corresponding mononuclear species ${ }^{57}$ and these complexes catalyze oxidation if the $\mathrm{Cu} \cdots \mathrm{Cu}$ distance is < $5 \AA .{ }^{31}$ But trinuclear complexes exhibiting catecholase activity are relatively rare. Previous studies on the catalytic oxidations of catechol derivatives demonstrated that the reaction needs the cooperation of two close copper centers ${ }^{58}$ to enable the binding of the catechol as a bridging ligand and allow a fast two-electron transfer process. However coordination of 3,5-DTBC in the trinuclear complex may occur to two metal center, without involvement of the third metal center. Similar conclusions had been reached by Gullotti et.al. ${ }^{59}$ In this study, the central nickel(II) and copper(II) ions of the trinuclear complexes are square-planar environment, these trinuclear complexes with oxime bridges (3-6) can be considered as a homodinuclear nickel(II)-nickel(II) and copper(II)-copper(II) systems. Therefore, trinuclear complexes are more reactive towards the oxidation of catechol than the corresponding mononuclear species in this study.

Catalase-like Activity Studies: The catalase-like function of the complexes in the presence of the base imidazole to disproportionate $\mathrm{H}_{2} \mathrm{O}_{2}$ into $\mathrm{H}_{2} \mathrm{O}$ and $\mathrm{O}_{2}$ was examined by volumetric measurements of evolved dioxygen. In the absence of heterocyclic base, the complexes decompose hydrogen peroxide slowly but the decomposition of $\mathrm{H}_{2} \mathrm{O}_{2}$ is enhanced in the presence of a heterocyclic base such as imidazole because of its strong $\pi$-donating ability. ${ }^{60}$ On the other hand heterocyclic bases themselves cause only a very slight disproportionation of the peroxide. It was found that complex 2 and the trinuclear complexes except complex $\mathbf{3}$ have shown catalase-like activity. Fig. 4 shows the amounts of oxygen evolved against time curves for hydrogen peroxide decomposition catalyzed by various trinuclear complexes. As a result of catalase-like activity studies, homotrinuclear $\mathrm{Cu}(\mathrm{II})$ complex is more active towards catalytic decomposition of hydrogen peroxide than the other synthesized complexes. The catalytic activities of the complexes are in the following order: $\mathbf{6}>\mathbf{5}>\mathbf{4}>\mathbf{2}$.

Interaction of Complexes with Double-Stranded DNA: The cleavage activity of the ligand $\left(\mathbf{H}_{2} \mathbf{L}\right)$, its mononuclear nickel(II) (1) and copper(II) (2), trinuclear nickel(II)-copper(II) complexes (3-6) has been determined in the absence or presence of $\mathrm{H}_{2} \mathrm{O}_{2}$ as a cooxidant from gel electrophoresis based on their ability to convert supercoiled pBR322 DNA to nicked circular DNA and linear DNA forms (Figure 5, 6 Table 4, 5). In fact, we recently published some preliminary results ${ }^{16,41}$ which demonstrated that some copper(II) complexes were able to promote DNA cleavage under physiological $\mathrm{pH}$ conditions (6.1 and 8.0). DNA cleavage was analyzed by monitoring the conversion of supercoiled DNA (Form I) to nicked circular DNA (Form II) and linear DNA (Form III) in aerobic condition. When circular plasmid DNA is subjected to electrophoresis, 
relatively fast migration will be observed in the intact supercoiled form (form I). If scission occurs on one strand (nicking), the supercoiled will relax to generate a slower moving open circular form (form II). If both strands are cleaved, a linear form (form III) that migrates between form I and form II will be generated. ${ }^{61,62}$ The results of the gel electrophoresis separations of plasmid pBR322 DNA by the ligand and its complexes (1-6) in the absence or presence of $\mathrm{H}_{2} \mathrm{O}_{2}$ are depicted in the Fig. 5 and 6. Control experiments are applied using only DNA and DNA $+\mathrm{H}_{2} \mathrm{O}_{2}$. As shown in Fig. 5, incubation of the pBR322 DNA at $37^{\circ} \mathrm{C}$ for $2 \mathrm{~h}$ with $1.5 \mu \mathrm{g}$ of the compounds cause the conversion of form I to form II and form III. In the ligand, mononuclear complexes (1-2) and trinuclear nickel complexes (3-4), the intensities of the circular supercoiled DNA (Form I) bands are found decrease, while that of nicked DNA bands (Form II) and linear DNA bands (Form III) increase slightly (Lane 2-6, respectively) in the absence of $\mathrm{H}_{2} \mathrm{O}_{2}$. In the trinuclear copper complexes (5-6), the cleavage is found to be much more efficient, it cleaves the supercoiled pBR322 DNA into form II and form III and the circular supercoiled DNA (Form I) band reduces considerably (Lane 7 and 8). The cleavage efficiency after incubation for $2 \mathrm{~h}$ in the absence of $\mathrm{H}_{2} \mathrm{O}_{2}$, follows the order: $\mathbf{5}>\mathbf{6}>$ other compounds. The cleavage percentages are listed in Table 4. These results indicate that the examined complexes induces very similar conformational changes in supercoiled DNA as conversion of supercoiled form to nicked form than a linear form in a sequential manner. But ligand and mononuclear complexes (1-2) are less effective than trinuclear copper complexes (5-6). The different DNA cleavage efficiency of the ligand and the complexes may be due to the different binding affinity of the complexes to DNA. ${ }^{63-65}$

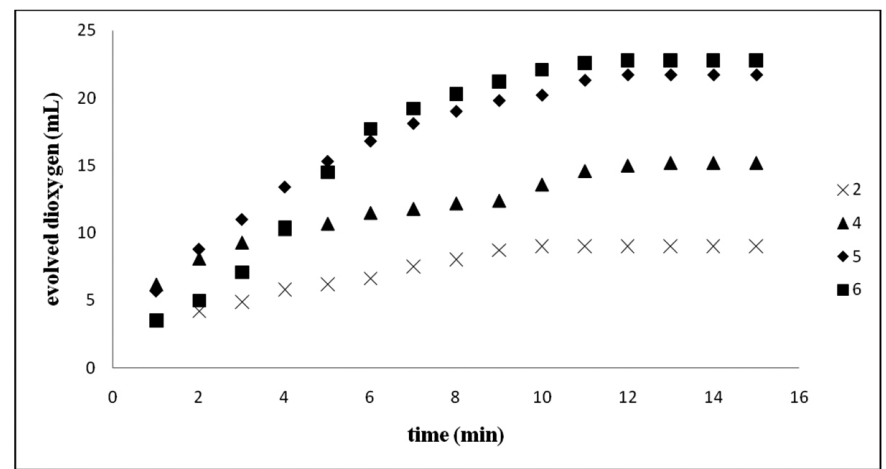

Figure 4. Time courses of dioxygen evolution in the disproportionation of $\mathrm{H}_{2} \mathrm{O}_{2}$ by complexes in DMF. [complex] $=0.005 \mathrm{mmol},\left[\mathrm{H}_{2} \mathrm{O}_{2}\right]=1.33 \mathrm{mmol}$, $298 \mathrm{~K}$.

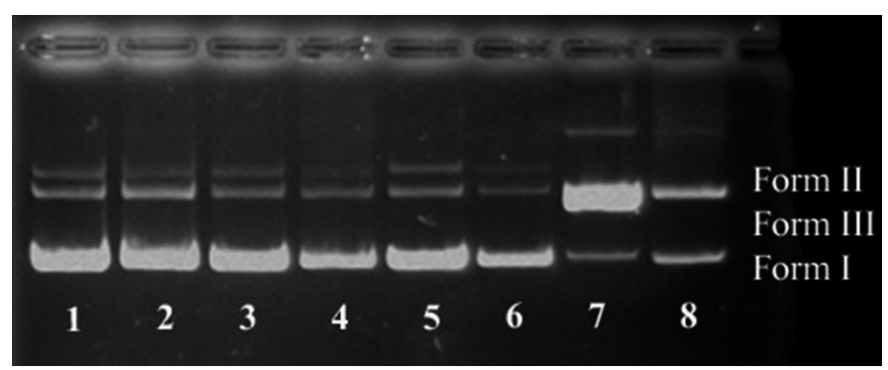

Figure 5. Gel electrophoresis diagram showing the cleavage data of pBR322 plasmid DNA by the ligand and its complexes in DMF -Tris buffer medium $(\mathrm{pH} 8.0)$ in air after incubation at $37^{\circ} \mathrm{C}$ for $2 \mathrm{~h}$. Lane 1 , untreated pBR322 plasmid DNA; lanes 2-8, pBR322 plasmid DNA + the compounds (the compounds $=\mathrm{H}_{2} \mathrm{~L}, \mathbf{1}, \mathbf{2}, \mathbf{3}, \mathbf{4}, \mathbf{5}, \mathbf{6}$, respectively)
Table 4. DNA cleavage data of $\mathrm{pBR} 322$ plasmid DNA by the ligand $\left(\mathrm{H}_{2} \mathrm{~L}\right)$ and its complexes $(\mathbf{1}-\mathbf{6})$ absence of $\mathrm{H}_{2} \mathrm{O}_{2}$

\begin{tabular}{|c|c|c|c|c|c|}
\hline Lane no & $\begin{array}{c}\text { Reaction } \\
\text { conditions }\end{array}$ & $\begin{array}{c}\text { Ink. Time } \\
\text { (hour) }\end{array}$ & $\begin{array}{c}\text { Form I } \\
\% \text { SC }\end{array}$ & $\begin{array}{c}\text { Form II } \\
\% \text { NC }\end{array}$ & $\begin{array}{c}\text { Form III } \\
\% \text { LC }\end{array}$ \\
\hline 1 & DNA & 2 & 91.01 & 1.80 & 7.19 \\
\hline 2 & DNA+ $\mathrm{H}_{2} \mathrm{~L}$ & 2 & 82.65 & 2.95 & 14.40 \\
\hline 3 & DNA+ 1 & 2 & 83.01 & 4.00 & 12.99 \\
\hline 4 & DNA+ 2 & 2 & 81.17 & 4.77 & 14.06 \\
\hline 5 & DNA+3 & 2 & 78.43 & 8.05 & 13.52 \\
\hline 6 & DNA+4 & 2 & 83.88 & 6.54 & 9.57 \\
\hline 7 & DNA+5 & 2 & 11.69 & 8.69 & 79.62 \\
\hline 8 & DNA+ 6 & 2 & 40.53 & 6.78 & 52.69 \\
\hline
\end{tabular}

SC, NC, LC are supercoiled, nicked circular and linked circular forms of DNA, respectively. ND: not detected.

Table 5. DNA cleavage data of $\mathrm{pBR} 322$ plasmid DNA by the ligand $\left(\mathrm{H}_{2} \mathrm{~L}\right)$ and its complexes $(\mathbf{1}-\mathbf{6})$ presence of $\mathrm{H}_{2} \mathrm{O}_{2}$

\begin{tabular}{|c|c|c|c|c|c|c|}
\hline $\begin{array}{l}\text { Lane } \\
\text { no }\end{array}$ & $\begin{array}{l}\text { Reaction } \\
\text { conditions }\end{array}$ & $\begin{array}{l}\text { Ink. } \\
\text { Time } \\
\text { (hour) }\end{array}$ & $\begin{array}{l}\text { Form } \\
\text { I } \\
\% S C\end{array}$ & $\begin{array}{c}\text { Form } \\
\text { II } \\
\% \mathrm{NC}\end{array}$ & $\begin{array}{c}\text { Form } \\
\text { III } \\
\% \text { LC }\end{array}$ & $\begin{array}{c}\text { Form } \\
\text { III } \\
\% \mathrm{SF}\end{array}$ \\
\hline 1 & $\mathrm{DNA}+\mathrm{H}_{2} \mathrm{O}_{2}$ & 2 & 87.92 & 12.08 & ND & ND \\
\hline 2 & $\mathrm{DNA}+\mathrm{H}_{2} \mathrm{~L}+\mathrm{H}_{2} \mathrm{O}_{2}$ & 2 & 79.26 & 20.74 & ND & $\mathrm{ND}$ \\
\hline 3 & $\mathrm{DNA}+\mathbf{1}+\mathrm{H}_{2} \mathrm{O}_{2}$ & 2 & 75.18 & 24.82 & ND & ND \\
\hline 4 & $\mathrm{DNA}+\mathbf{2}+\mathrm{H}_{2} \mathrm{O}_{2}$ & 2 & 54.33 & 45.67 & ND & ND \\
\hline 5 & $\mathrm{DNA}+\mathbf{3}+\mathrm{H}_{2} \mathrm{O}_{2}$ & 2 & 70.00 & 30.00 & ND & ND \\
\hline 6 & $\mathrm{DNA}+\mathbf{4}+\mathrm{H}_{2} \mathrm{O}_{2}$ & 2 & 40.93 & 49.88 & ND & 9.18 \\
\hline 7 & $\mathrm{DNA}+\mathbf{5}+\mathrm{H}_{2} \mathrm{O}_{2}$ & 2 & ND & 15.48 & 84.52 & ND \\
\hline 8 & $\mathrm{DNA}+\mathbf{6}+\mathrm{H}_{2} \mathrm{O}_{2}$ & 2 & ND & 35.96 & 64.04 & ND \\
\hline
\end{tabular}

SC, NC, LC, SF are supercoiled, nicked circular and linked circular, smaller fragment forms of DNA, respectively. ND: not detected

Fig. 6 shows agarose gel electrophoresis patterns for the cleavage of plasmid pBR322 DNA after treatment with $\mathrm{H}_{2} \mathrm{O}_{2}$ as a cooxidant. The degradation of pBR322 DNA is also dependent on cooxidant used. The pBR322 DNA treated with the ligand $+\mathrm{H}_{2} \mathrm{O}_{2}$ shows only insignificant changes in the form levels compared with the DNA $+\mathrm{H}_{2} \mathrm{O}_{2}$. Namely, the ligand alone is cleavage-inactive. In the mononuclear complexes $(\mathbf{1}, \mathbf{2})$ and trinuclear nickel complexes $(\mathbf{3}$, 4), the intensities of the circular supercoiled DNA (Form I) bands are found decrease, while that of nicked DNA bands (Form II) increase apparently (Lane $3-6$, respectively) in the presence of $\mathrm{H}_{2} \mathrm{O}_{2}$. Furthermore, in the trinuclear $\mathrm{Ni}_{2} \mathrm{Cu}$ complex (4), the cleavage is found to be more efficient, they cleaved the supercoiled pBR322 DNA into form II and much smaller fragments (Lane 6). In the trinuclear copper complexes $(\mathbf{5 , 6})$, the cleavage is found to be much more efficient, it cleaves the supercoiled pBR322 DNA into form II and form III and the circular supercoiled DNA (Form I) band is disappeared completely (Lane 7 and 8 ). The activity of the trinuclear $\mathrm{Cu}_{3}$ complex $(\mathbf{6})$ is weaker than the trinuclear $\mathrm{Cu}_{2} \mathrm{Ni}$ complex (5). The intensity of the linear DNA band of the complex 5 (Line 7) is found increase compared with complex 6 (Line 8). The cleavage activities of the compounds after treatment with $\mathrm{H}_{2} \mathrm{O}_{2}$ as a cooxidant are in the following order: $\mathbf{5}>\mathbf{6}>\mathbf{4}>\mathbf{2}>\mathbf{3}>\mathbf{1}>\mathbf{H}_{2} \mathbf{L}$. These observations suggest that the complexes mediated cleavage reaction proceed via the oxidative pathway mechanism and imply that the singlet oxygen playing a role in the cleavage chemistry. These results are similar to that observed for some $\mathrm{Cu}(\mathrm{II})$ and $\mathrm{Ni}(\mathrm{II})$ complexes as chemical nuclease. ${ }^{66,67}$ 


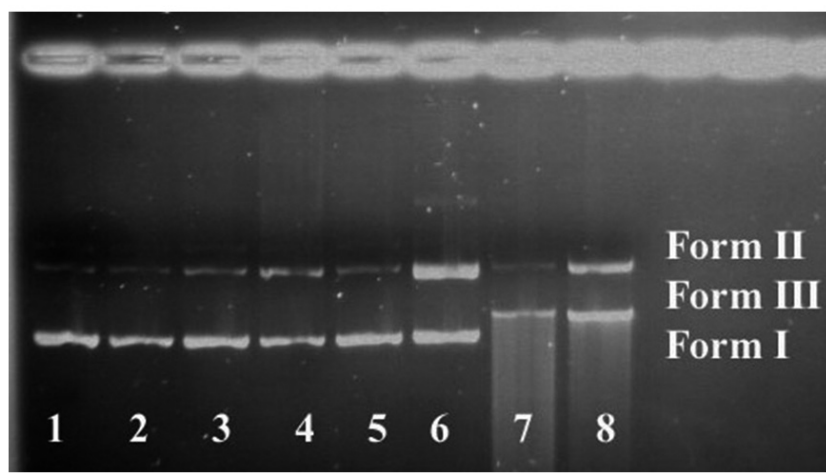

Figure 6. Gel electrophoresis diagram showing the cleavage data of pBR322 plasmid DNA by the ligand and its complexes in DMF -Tris buffer medium ( $\mathrm{pH}$ 8.0) in air after incubation at $37^{\circ} \mathrm{C}$ for $2 \mathrm{~h}$. Lane 1 , pBR322 plasmid DNA $+\mathrm{H}_{2} \mathrm{O}_{2}$; lanes $2-8, \mathrm{pBR} 322$ plasmid DNA + the compounds + $\mathrm{H}_{2} \mathrm{O}_{2}$ (the compounds $=\mathrm{H}_{2} \mathrm{~L}, \mathbf{1}, \mathbf{2}, \mathbf{3}, \mathbf{4}, \mathbf{5}, \mathbf{6}$, respectively)

\section{CONCLUSION}

In this work, we have described the mononuclear $\mathrm{Ni}(\mathrm{II})$ and $\mathrm{Cu}(\mathrm{II})$ and trinuclear homo- and heterometallic $\mathrm{Ni}(\mathrm{II})$ and $\mathrm{Cu}(\mathrm{II})$ complexes obtained through the use of the dioxime ligand and 1,10-phenantroline. The spectral, elemental and magnetic susceptibility data conform to the proposed structure of the (Fig. 1). The conductance data indicate that the mononuclear complexes are non-electrolytes and the trinuclear complexes containing perchlorate ions behave as 1:2 electrolytes. In addition we have tested the catalytic activity of the complexes toward the disproportionation of hydrogen peroxide. The catalytic results indicated that homotrinuclear copper(II) complexes have good catalase activity and may be suitable and functional as a model for the pseudocatalase enzyme. Furthermore the trinuclear complexes are able to oxidize 3,5-di-tert-butylcatechol to the corresponding $o$-quinone with distinct catalytic activity. Trihomonuclear copper(II) complex is the most active catalyst to show catecholase activity. We have also tested the DNA cleavage activity of the ligand and its complexes. The DNA cleavage results showed that the trinuclear $\mathrm{Cu}_{2} \mathrm{Ni}$ complex (5) and $\mathrm{Cu}_{3}$ complex (6) could effectively cleave supercoiled DNA to form nicked and linear DNA. The cleavage in the complexes was found to be much more efficient in the presence of hydrogen peroxide as co-oxidant.

\section{REFERENCES}

1. L. Tschugaeff, Ber. 40, 3498, (1907)

2. A. Chakravorty, Coord. Chem. Rev. 13, 1, (1974)

3. F. Karipcin, F. Arabali, I. Karatas, J. Chil. Chem. Soc. 51, 982, (2006)

4. F. Karipcin, S. Ilican, Y. Caglar, M. Caglar, B. Dede, Y. Sahin, J. Organomet. Chem. 692, 2473, (2007)

5. F. Karipcin, M. Erdem-Tuncmen, G. Baskale-Akdogan, B. Dede, Polish. J. Chem. 83, 525, (2009)

6. Y. Gok, H. Kantekin, New J. Chem. 19, 461, (1995)

7. F. Karipcin, B. Dede, Y. Caglar, D. Hür, S. Ilican, M. Caglar, Y. Sahin, Optic Commun. 272, 131, (2007)

8. A. Kilıc, E. Tas, I. Y1lmaz, J. Chem. Sci. 121, 43, (2009)

9. T. Gajda, A. Jancso, S. Mikkola, H. Lönnberg, H. Sirges, Dalton Trans. 8 , $1757,(2002)$

10. O. Iranzo, T. Elmer, J.P. Richard, J.R. Morrow, Inorg. Chem. 42, 7737, (2003)

11. A. Jancso, I. Török, K. Hegetschweiler, T. Gajda, Arkivoc 3, 217, (2009)

12. K.W. Wellington, P.T. Kaye, G.M. Watkins, Arkivoc 14, 301, (2009)

13. R. Lescouezec, L.M. Toma, J. Vaissermann, M. Verdaguer, F.S. Delgado, C. Ruiz-Perez, F. Lloret, M. Julve, Coord Chem. Rev. 249, 2691, (2005)

14. D. Ghoshal, A.K. Ghosh, T.K. Maji, J. Ribas, G. Mostafa, E. Zangrando, N.R. Chaudhuri, Inorg. Chim. Acta 359, 593, (2006)

15. J. Gao, A.E. Martell, J.H. Reibenspies, Inorg. Chim. Acta 346, 32, (2003)

16. B. Dede, I. Ozmen, F. Karipcin, Polyhedron 28, 3967, (2009)

17. Q.H. Zhou, P. Yang, Inorg. Chim. Acta 359, 1200, (2006)

18. Y.P. Li, Y.B. Wu, J. Zhao, P. Yang, J. Inorg. Biochem. 101, 283, (2007)

19. R.S. Kumar, S. Arunachalam, Eur. J. Med. Chem. 44, 1878, (2009)

20. M. Geraghty, V. Sheridan, M. McCann, M. Devereux, V. McKee, Polyhedron 18, 2931, (1999)

21. M.A. Zoroddu, S. Zanetti, R. Pogni, R. Basosi, J. Inorg. Biochem. 63, 291 ,
(1996)

22. J.B. Sumner, J. Biol. Chem. 69, 435 (1926)

23. D. Volkmer, A. Horstmann, K. Griesar, B. Haase, B. Krebs, Inorg. Chem. 35, 1132, (1996)

24. D.E. Fenton, Biocoordination Chemistry. Oxford University Press, New York, 1995.

25. J. Kaizer, R. Csonka, G. Speier, M. Giorgi, M. Reglier, J. Mol. Catal. A-Chem. 236, 12, (2005)

26. I. Szilagyi, L. Horvath, I. Labadi, K. Hernadi, I. Palinko, T. Kiss, Cent. Eur. J. Chem. 4, 118, (2006)

27. D. Kovala-Demertzi, S.K. Hadjikakou, M.A. Demertzis, Y. Deligiannakis, J. Inorg. Biochem. 69, 223, (1998)

28. Y. Gultneh, A. Farooq, K.D. Karlin, S. Liu, J. Zubieta, Inorg. Chim. Acta $211,171,(1993)$

29. O. Hayaish, E. Niki, M. Kondo, Y. Yoshikawa (Eds.), Medical, Biochemical and Chemical Aspects of Free Radicals. Elsevier, Amsterdam, 1990.

30. M.J. Penalver, A.N.P. Hiner, J.N. Rodriguez-Lopez, F. Garcia-Canovas, J. Tudela, BBA-Protein Struct. 1597, 140, (2002)

31. R. Than, A.A. Feldman, B. Krebs, Coord. Chem. Rev. 182, 211, (1999)

32. D.S. Sigman, T.W. Bruice, A. Mazumder, C.L. Sutton, Acc. Chem. Res. 26, 98, (1993)

33. A.R. Chakravarty, P.A.N Reddy, B.K. Santra, A.M. Thomas, Proc. Indian Acad. Sci. 114, 391, (2002)

34. A.M. Thomas, A.D. Naik, M. Nethaji, A.R. Chakravarty, Inorg. Chim. Acta, 357, 2315, (2004)

35. D.S. Sigman, Biochem. 29, 9097, (1990)

36. R. Hettich, H.-J. Schneider, J. Am. Chem. Soc. 119, 5638, (1997)

37. E.L. Hegg, J.N. Burstyn, Coord. Chem. Rev. 173, 133, (1998)

38. M. Gonzalez-Alvarez, G. Alzuet, J. Borras, M. Pitie, B. Meunier, J. Biol. Inorg. Chem. 8, 644, (2003)

39. S. Dhar, A.R. Chakravarty, Inorg. Chem. 42, 2483, (2003)

40. S. Dhar, D. Senapati, P.K. Das, P. Chattopadhyay, M. Nethaji, A.R. Chakravarty, J. Am. Chem. Soc. 125, 12118, (2003)

41. B. Dede, I. Ozmen, F. Karipcin, M. Cengiz, Appl. Organomet. Chem. 23, $512,(2009)$

42. N. Levin, W.H. Hartung, J. Org. Chem. 7, 408, (1942)

43. A. Elmottaleb, M. Ramadan, I.M. El-Mehasseb, R.M. Issa, Transit. Metal Chem. 22, 529, (1997)

44. F. Karipcin, B. Dede, S. Percin-Özkorucuklu, E. Kabalcılar, Dyes Pigments $84,14,(2010)$

45. W.J. Geary, Coord. Chem. Rev. 7, 81, (1971)

46. O. Kahn, Structure Bond. 68, 89, (1987)

47. S.-W. Zhang, S.-P. Yan, D.-Z. Liao, Z.-H. Jiang, G.-L. Wang, Transit. Metal Chem. 22, 42, (1997)

48. C.N. Verani, E. Rentschler, T. Weyhermuller, E. Bill, P. Chaudhuri, Dalton Trans. 2000, 23, 4263(1997)

49. P. Chaudhuri, Coord. Chem. Rev. 243, 143, (2003)

50. F. Karipcin, F. Arabali, I. Karatas, Russ. J. Coord. Chem. 32, 109, (2006)

51. K.N. Kumar, R. Ramesh, Polyhedron 24, 1885 (2005)

52. S.A. Ali, A.A. Soliman, M.M. Aboaly, R.M. Ramadan, J. Coord. Chem. $55,1161,(2002)$

53. M. Kandaz, A. Koca, A.R. Ozkaya, Polyhedron 23, 1987, (2004)

54. M.M. Aly, A.O. Boghlaf, N.S. Ganji, Polyhedron 4, 1301, (1985)

55. J. Reim, B. Krebs, Dalton Trans. 20, 3793, (1997)

56. R. Wegner, M. Gottschaldt, H. Gorls, E.G. Jager, D. Klemm, Chem. Eur. J. $7,2143,(2001)$

57. U. Casellato, S. Tamburini, P.A. Vigato, A. De Stefani, M. Vidali, D.E. Fenton, Inorg. Chim. Acta 69, 45, (1983)

58. E. Monzani, G. Battaini, A. Perotti, L. Casella, M. Gullotti, L. Santagostini, G. Nardin, L. Randaccio, S. Geremia, P. Zanello, G. Opromolla, Inorg. Chem. 38, 5359, (1999)

59. M. Gullotti, L. Santagostini, R. Pagliarin, A. Granata, L. Casella, J. Mol. Catal. A 235, 271, (2005)

60. E.J. Larson and V.L. Pecoraro, in: V.L. Pecoraro (Ed.), Manganese Redox Enzymes. Wiley-VCH, New York, 1992.

61. Q.L. Zhang, J.G. Liu, H. Chao, G.Q. Xue, L.N. Ji, J. Inorg. Biochem. 83, 49, (2001)

62. S. Anbu, M. Kandaswamy, P. Suthakaran, V. Murugan, B. Varghese, J. Inorg. Biochem. 103, 401, (2009)

63. J. Liu, T.X. Zhang, T.B. Lu, L.H. Qu, H. Zhou, Q.L. Zhang, L.N. Ji, J. Inorg. Biochem. 91, 269, (2002)

64. Q.Q. Zhang, F. Zhang, W.G. Wang, X.L. Wang, J. Inorg. Biochem. 100, $1344,(2006)$

65. D.Y. Kong, J. Reibenspies, J.G. Mao, A. Clearfield, A.E. Martell, Inorg. Chim. Acta 342, 158, (2003)

66. M.S.S. Babu, K.H. Reddy, P.G. Krishna, Polyhedron 26, 572 (2007)

67. L.N. Zhu, D.M. Kong, X.Z. Li, G.Y. Wang, J. Wang, Y.W. Jin, Polyhedron $29,574(2010)$. 